\title{
Digital Education Quality Assessment System at Municipal Level
}

\author{
Sovetova N.P.* Aksyutina S.V.
}

\author{
Vologda State University, Vologda, Russia \\ *Corresponding author. Email: n7777777@yandex.ru
}

\begin{abstract}
The relevance of the study of quality of education assessment system is caused by the contradiction between the objectively increasing requirements of the state and society for the realization of the rights of children to receive publicly available and high-quality free general education in full compliance with the requirements of federal state educational standards and the insufficient development of theoretical and methodological and methodological foundations of in-school education quality management. This article discusses theoretical approaches to assessing the quality of education, legal regulation of assessing the quality of education in Russia, analyzes the approaches to assessing the quality of education. Based on the analysis, the authors proposed a model of an intra-school system for assessing the quality of education, developed assessment indicators, and examined the possibilities of digitalizing assessment procedures.
\end{abstract}

Keywords: education quality assessment, municipal level, digital technologies

\section{INTRODUCTION}

In Russia, at all levels of management, education quality management systems are being built in order to ensure the fulfillment of a social order, guarantee students and their parents a certain level of quality, reduce the likelihood of unintended results, and ensure managed development. In accordance with the state program "Development of Education of the Vologda Region for 2021-2025", the goal of developing a regional education system is to increase the availability of quality education that meets the requirements of innovative development of the region's economy, the modern needs of society and every citizen. A whole range of functions is implemented in the quality management loops: from forecasting, modeling, goal setting, coordination to control, assessment, analysis, and accounting. Each of the functions is built into the management cycle, ensures the adoption of a certain managerial decision to improve quality (warning, corrective).

At present, Russia is participating in international comparative studies of the quality of education, such as TIMSS (assessment of the quality of science and mathematics education), RISA (assessment of students' ability to use knowledge and experience to solve practical problems), PIRLS (assessment of reading literacy), ICILS

(study of information and computer literacy), ICCS (quality of civic education). Equally significant are international comparative studies regarding the level of training of teachers: TEDS (assessment of the quality of training of future teachers), TALIS (study of the features of teaching and learning).
The task of international research is to assess the training of students at different levels of education in countries with different educational systems, and as a result to identify factors affecting the level of this training. Based on the results of these comparisons, decisions are being made to reform Russian education.

An analysis of approaches to assessing the quality of education allows us to conclude that the prevailing external assessment is when the school as a whole, students are only objects of study, however, the consumers of educational services (administration, teachers, representatives of public administration bodies of the school, parent community, partners are the results of the study schools) learn only in a generalized form, which in no way can affect the quality of education in a particular educational institution.

Meanwhile, the need to develop, implement and apply in each educational organization an internal system for assessing the quality of education is provided for in paragraph 3 of Art. 28 of Federal Law "On Education in the Russian Federation". The internal system will have to supplement and clarify the external one, supply all the interested parties with the necessary information about the quality of the functioning and development of the educational system, the quality of students' educational achievements, and the main parameters of the educational process.

Objective assessment procedures for the quality of education contribute to an effective management system and the adoption of quality management decisions. The correctness of the assessment is determined by the quality of the measuring materials, the reliability of the data collected, the validity of the interpretation and use of the information received. But the directions of improving the 
procedures for assessing educational achievements of students reflect only part of the tasks that need to be solved for the effective functioning of the system of internal assessment of the quality of education. The quality management system should contain blocks that reflect the performance of the entire educational organization.

\section{RESEARCH METHODOLOGY}

The methodological basis of the study was a complex of general scientific and special methods of cognition. In the course of the study, such general scientific methods were used as analysis, synthesis, generalization, historical, graphic method; special methods of cognition: formallogical method and specific sociological.

The purpose of the study is to develop indicators for an intra-school assessment of the quality of education in a municipal educational institution and to substantiate the need to use digital technologies in assessing the quality of education.

The object of the study is a system for assessing the quality of education, the subject is a system of intra-school assessment of the quality of education in a comprehensive school. The study was conducted on the materials of the educational organization of the Vologda Region.

Problems of the quality of education in the managerial aspect are investigated in the works of A.G. Bermus, V.A. Bolotov, T.V. Arkhipova, M.S. Sagdieva, and others. The specifics of the concept of "quality of education" at the level of an educational institution is revealed in the works of V.I. Zagvyazinsky, N.A. Kulemin, V.P. Panasyuk, I.N. Shcherbo. Foreign experience in researching the problem of measuring the quality of educational services and developing competent management decisions on its basis is well diversified and deserves the undoubted attention of Russian scientists. The framework for education quality indicators proposed by UNESCO is of particular note. However, the development of indicators for assessing the quality of education at the level of general educational organizations, the possibility of using digital technologies to assess the quality of education in the secondary schools of Russia remain underdeveloped.

\section{RESULTS AND DISCUSSION}

The features of the development of modern Russian education impose quite high, fundamentally new requirements on its quality, which is reflected in a number of state, regional and industry regulatory documents. As noted in the national project of the Russian Federation "Education", implemented until 2024, the key task is "to ensure global competitiveness of Russian education and the Russian Federation becoming one of the 10 leading countries in the world in the quality of general education". The national project involves the implementation of four main areas of development of the education system: updating its content; creation of the necessary modern infrastructure; training of relevant professional personnel, their retraining and advanced training; the creation of the most effective mechanisms for managing this area.

Modern quality management assumes that the activities of the leader in this area can be effective only if it affects all aspects of the organization's work, starting with building its goals and policies and ending with the coordination of processes that ensure the functioning of the organization. At the same time, the leading task of management activity is to guarantee a level of education quality that meets both the requirements of regulatory documents and the needs of consumers.

The creation of a system for assessing the quality of education (hereinafter referred to as the SAQE) occupies a primary position in the development of education in the Russian Federation. This system will guarantee the security of students and their parents, teaching staff, educational authorities at all levels, employers with reliable information about the current state and development of the education system at different levels, which is emphasized in the state program of the Russian Federation "Education development for 2013-2020".

The main procedures established by FZ-273 “On Education in the Russian Federation" and providing an assessment of the quality of education are the federal state control over the quality of education and an independent assessment of the quality of education. Ensuring the functioning of the internal system for assessing the quality of education is the competence of the educational organization. At the same time, the internal system for assessing the quality of education (ISAQE) should become a regional subsystem (RSAQE), and then the all-Russian SAQE. This means that in every educational organization there should be an intraschool system for assessing the quality of education, uniform and easily integrated into the regional SAQE, allowing monitoring, control and managing the quality of education.

Different authors in modern pedagogy interpret the concept of "quality of education" in different ways. The difficulty in assessing the quality of education is precisely due to the large number of interpretations of the concept itself, and accordingly to the lack of unified approaches to its assessment. So, various authors $[1,2,3,5]$ argue that it is necessary to focus on different sides of its manifestation, considering both from the perspective of the subjects of the educational process, taking into account the hierarchy of socially significant characteristics, parameters, and from the perspective of the educational organization (provider) itself, providing a range of services that are adequate to the requirements of the federal state educational standard, the needs of the individual and society (consumers), taking into account the forecast of its activities in the future.

In this study, the author's interpretation of the concept of the quality of education is formulated taking into account the main provisions of the Federal State Educational Standard (FSES), the professional standard of the teacher, the Federal Law "On Education in the Russian Federation", which refers to the normative indicators of the educational institution, optimal conditions (organizational, technological, motivational, financial, informational and 
etc.) and regulated processes that ensure this quality of the educational process. The level of results is determined by the sum of meta-subject and subject skills, personal development. Assess the quality of education can not only the state in the person of the relevant authorities, but teachers, heads of educational organizations, students and their parents. Assessing the quality of all aspects of the educational organization's activity is possible only with the help of a representative system of indicators and criteria. Where the "criterion" is the basis for assessing the quality of education, and the indicator is a quantitative or qualitative characteristic of each direction separately.

One of the areas of assessment carried out within the framework of the regional system for assessing the quality of education since 2004 is the assessment of the quality of work of educational institutions. This assessment is based on the components of state assessment (licensing, accreditation, final certification, certification of teaching staff, monitoring of the education system) and selfassessment (self-examination of an educational institution, intermediate certification of students and the internal system for assessing the quality of education). The assessment is carried out both by participants in the educational process (students, parents), and citizens, experts, the public, independent organizations that are not participants in the educational process.

The regional system for assessing the quality of the Vologda Region represents a single information and educational space that includes organizational infrastructure (District Center for Continuing Education, Center for Assessing the Quality of Education); software and technology infrastructure, hardware infrastructure (Hardware), telecommunications infrastructure (network, IP-telephony). The main focus of the budgetary institution of the education system of the Vologda Region "Center for Informatization and Assessment of the Quality of Education" is the annual monitoring of population satisfaction with the quality of educational services, as well as supporting the education system of the Vologda Region in such major areas as informatization of education and distance education. In addition, department specialists annually compile a list of criteria and evaluation indicators, as well as analyze information on the quality of the services provided for each educational institution subordinate to the Department of Education.

One of the criteria for an independent assessment of the quality of education is to ensure the availability and openness of information about the educational organization. In the regional assessment, this criterion is monitored in the framework of monitoring the development of official websites of educational organizations in the region and monitoring the quality of educational achievements of graduates of grades 9 and 11 of general educational organizations of the region, implemented on the basis of the results of state final certification (hereinafter referred to as SFC). In the framework of this area, a quantitative and qualitative analysis of the results of the SFC is carried out, the main trends in the state of educational achievements of graduates of the region are identified.

The applied assessment of the individual elements of the quality of education is not systemic, completely independent and, most importantly, does not have any effect on the quality of educational services provided.

To take into account and influence the opinions of all subjects of educational relations on the development of the education system, it is necessary to use not individual elements of an independent assessment but to form a system of intraschool assessment of the quality of education (hereinafter referred to as ISAQE), which will have unified methodological, regulatory, criteria and organizational and technological approaches.

The first step in the formation of an assessment system is the development of a system of indicators for assessing the quality of education. As the "indicator" we consider it necessary to use the characteristic (qualitative or quantitative) of any feature of the structure or process. This characteristic will represent the result of measurements or calculations.

We propose to divide the quality of the content of education and its process into 5 separate elements (Figure 1), each of which will have its own set of indicators.

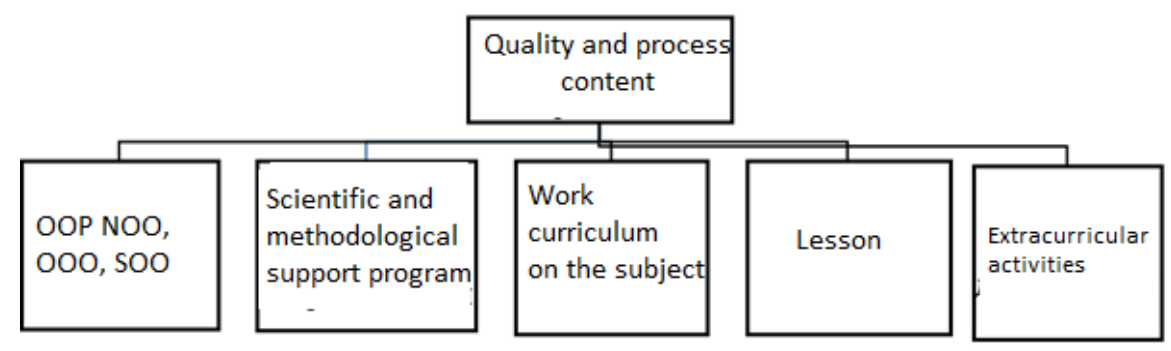

Figure 1 Quality and Content Assessment Objects

For each object we provide individual indicators of quality assessment. The system of indicators for evaluating the main educational program (MEP) is presented in Figure 2.
So, the program of scientific and methodological support can be evaluated by the main indicator: increasing the professional competence of the teacher (Figure 3). 


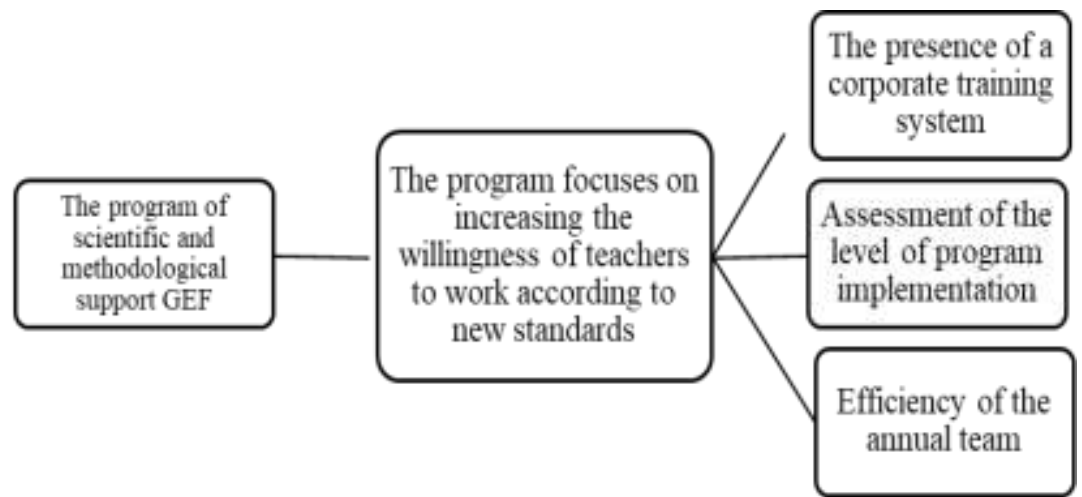

Figure 2 MEP Assessment Indicators

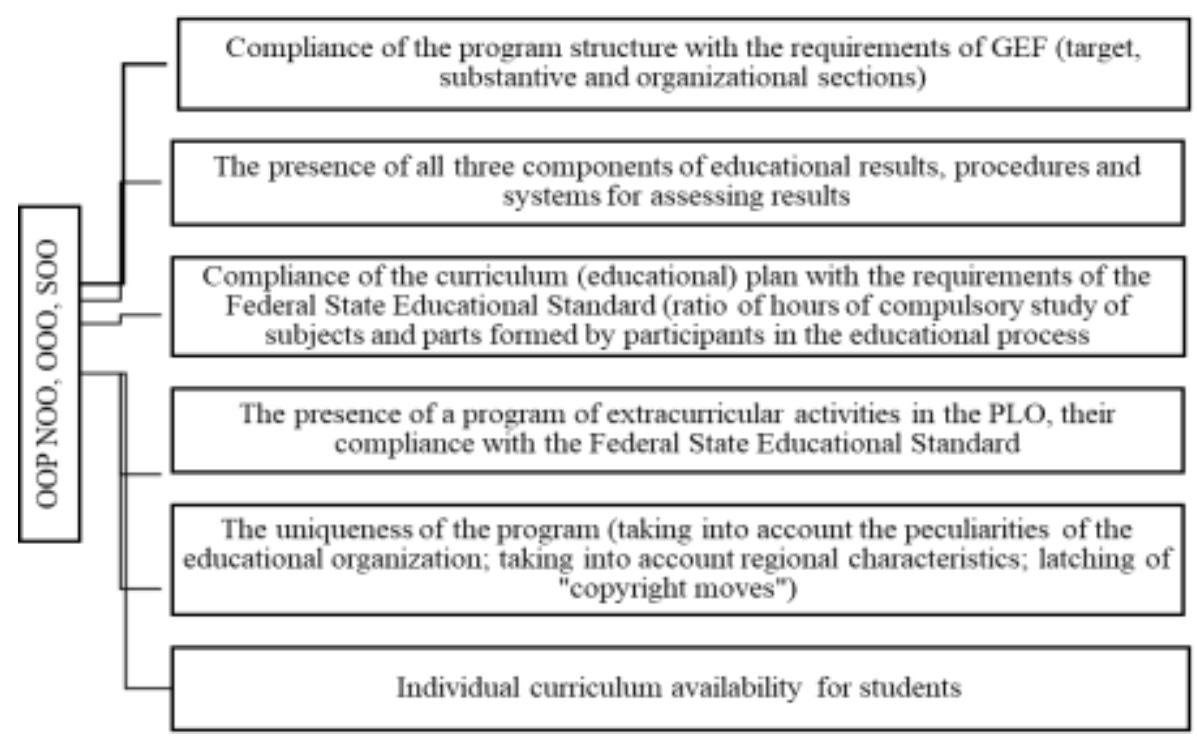

Figure 3 Indicators for the evaluation of scientific and methodological support

To evaluate work programs for a specific subject, we use three indicators: the compliance of the program structure with the requirements of the Federal State Educational Standard, the compliance of the program contents with the requirements of the Federal State Educational Standard, and the uniqueness of the program (author's contribution).

The program structure includes the relevant sections. The following elements are reflected in work programs: substantive content is focused on methods of action or on the amount of knowledge; reflected the use of modern educational technologies; the use of extracurricular activities has been taken into account; the presence in the program of internal monitoring (parameters, indicators, control and measuring materials). An indicator of the uniqueness of the program is to take into account the characteristics of the educational process of the organization, regional features; there is an author's approach in the part formed by the teacher.

A lesson can be assessed by one single indicator: the structure and content of the lesson meet the requirements of the Federal State Educational Standard. The indicator is the presence in the structure and content of the necessary components: goal-setting; the content of the lesson is adequate to the topic and purpose of the lesson, is optimal in volume and has a problem-search character, etc.; reflects the methods and forms of organization of cognitive activity; the use of modern educational technologies, including ICT tools (DER, EFT); lesson reflection.

Evaluation criteria for extracurricular activities include motivation of students for activities, the topic of the lesson; hidden or explicit (depending on form and design) statement of the purpose of the lesson; a description of the expected result (or anticipation of it, based on form and design); the clarity of the stages of the lesson, their relevance to the topic and purpose of the lesson; extracurricular activities reflect a variety of game, educational and other situations, its form differs from the lesson; students participate in setting the goal of the lesson, planning work; in the lesson, work is underway on the formation of the universal learning activities, the teacher correctly names the formed universal learning activities; the lesson contributes to the formation of value relationships, in the process of lesson the individual interests and needs of the student are taken into account; the lesson reflects the 
cooperation, active position, tolerance; students are included in situations of control and evaluation; at various stages of the lesson, methods of teaching reflection are used.

The system of indicators for assessing the quality of conditions can be represented in the following order in accordance with the objects of assessment (Figure 4): lesson; during the lesson, various forms of children's activities are reflected that contribute to the formation of

logical use of modern equipment; the content of the lesson includes creative and research assignments, role-playing situations, improvisation, the teacher offers original assignments that are appropriate to the age characteristics of the children and relevant to the goals and objectives of the

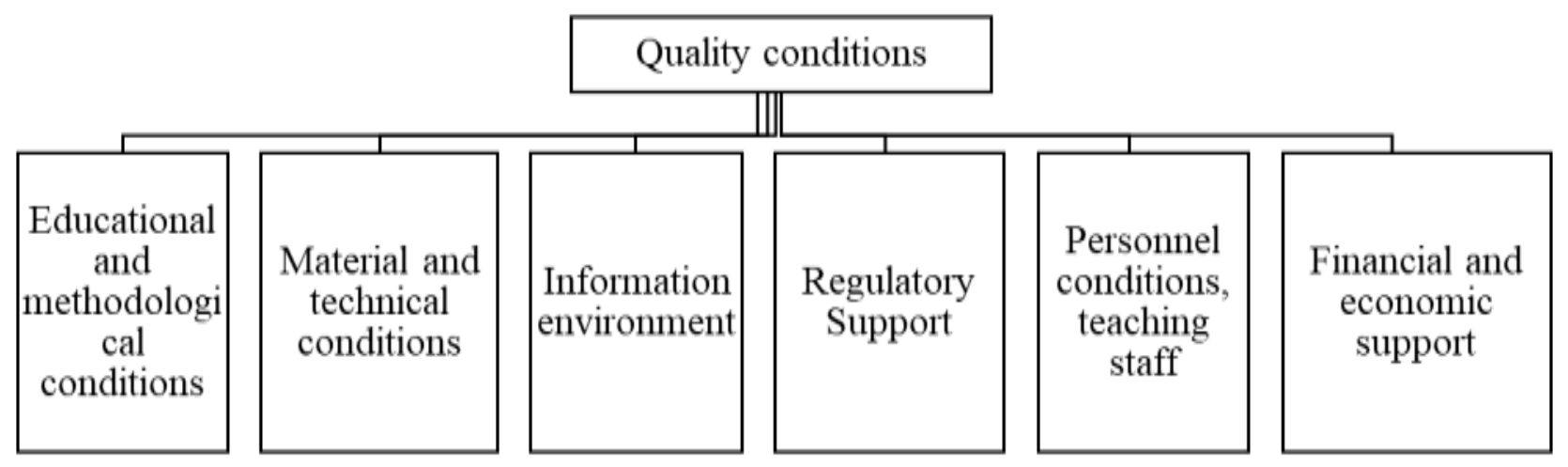

Figure 4 Condition Quality Assessment Indicators

1. The ability of a teacher to implement the basic educational program: level of education, teaching experience, qualification level, taking appropriate courses, etc.

2. The presence of developed legal acts that ensure the implementation of the MEP. Thus, as the indicators may figure developed and approved provisions on:

- $\quad$ educational process organization;

- organization of extracurricular activities;

- $\quad$ educational institution infrastructure;

- information environment of an educational institution;

- $\quad$ assessment system, forms, and procedures for intermediate and final certification of students;

- internal system for assessing the quality of education.

Job descriptions for all school workers have also been developed, and contracts have been concluded with parents (legal representatives) of the students in the school.

3. The level of remuneration of teachers: the dynamics of the level of remuneration of teachers and workers, the presence in the Regulation on remuneration of employees of incentive surcharges, the presence in the system of financial and economic support of both budget and non-budget sources of financing.

4. Compliance of the school infrastructure with the requirements of the Federal State Educational Standard: the level of equipment of classrooms, the availability of premises in the school infrastructure for the organization of the educational process, the availability of a medical office and medical services, and hot meals.

5. Compliance of the information environment with the requirements of the Federal State Educational Standard: Internet accessibility (speed, output frequencies), the number of students on one computer, the number of mobile classes, the availability of digital laboratories, the presence of a local network, electronic document management, the use of Internet resources to host children's educational products, etc.

6. site mobility: timely reflection of the implementation of the educational process, news and achievements of teachers and students.

7. the conformity of the teaching materials of educational programs with the requirements of the Federal State Educational Standard: the level of provision of the educational process with textbooks complying with the requirements of the Federal State 
automated information management systems (hereinafter referred to as AIMS), i.e. computer programs that significantly save time, human resources during the collection, processing, storage, transmission of information does not exist.

The developed project program from the point of view of functionality should include: data input from various workplaces; generating a report in the form in accordance with the requirements of the user; the ability to send reports by e-mail; protection of access to data from unauthorized access using passwords (security function). Recommended application requirements include separation of access to data by user groups (administrators - full access; operators - partial access); the structure and list of indicators and units of their measurement are set by the administrator; generation of a report for an arbitrary period for arbitrary indicators; the program does not require additional user training, provides quick access to all functionality.

As part of the study, the possibility of using a platform used in an educational organization that requires minor technical improvement was considered for assessment. This platform of the program will allow maintaining a personal account of a pupil of a comprehensive school as a means of assessing the quality of education and its improvement. work with the information presen
the quality of this information.

Thus, we consider the introduction of digital electronic document management as a priority and appropriate in terms of assessing the quality of education. At the moment,

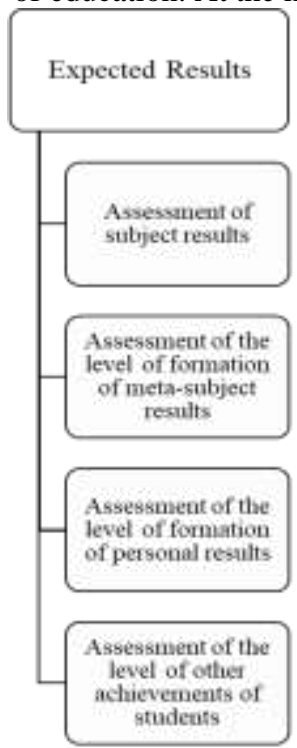

Figure 5 Results Quality Assessment Indicators

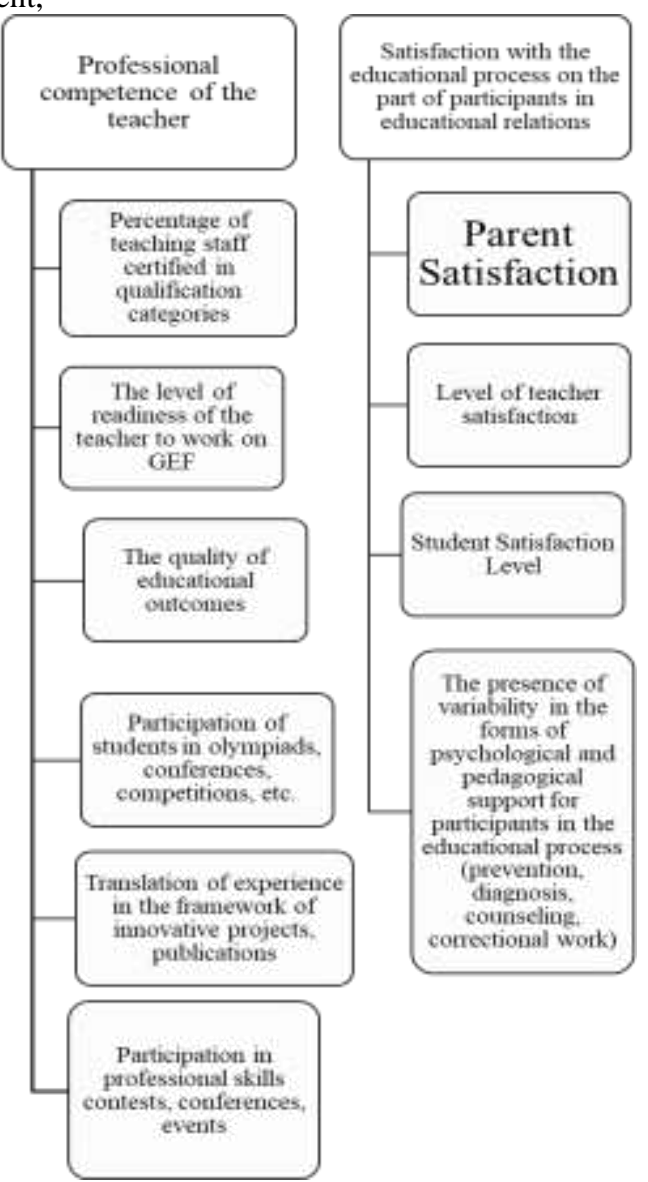


The student's personal account, posted on the school's website, will record and accumulate student achievements; create an achievement rating; evaluate the progress of the student in certain areas for a certain period of study; analyze achievements as a result of participation in olympiads, contests, conferences; track achievements in other fields of science, education, sports, creativity, social activities. The procedure for registering participants, as well as users of your personal account, entering information and processing it, is determined by the procedure for operating the information system, approved in the established manner. The processing of personal data obtained during the filling out of your personal account is carried out in accordance with Federal Law of July 27, 2006, No. 152-FZ "On Personal Data".

\section{CONCLUSIONS}

1. The difficulty in creating a single model for assessing the quality of education is due to the large number of interpretations of the concept of "quality" in general, and the concept of "quality of education" in particular. The opinions of various authors were divided on the need to focus on different sides of the manifestation of quality, for example, from the perspective of the subjects of the educational process, taking into account the hierarchy of socially significant characteristics, parameters, to the need to take into account the position of the educational organization itself (provider), which provides a range of services that are adequate to the requirements of the federal state educational standard requirements of the individual and society (consumers), taking into account the forecast of its activities in the future.

2. At the stage of the analysis of the intra-school assessment of the quality of education on the example of a particular educational institution, the absence of unified approaches to the principles, terms, procedures of the ISAQE ensuring their continuity was revealed; lack of clear criteria and individual indicators for assessing the quality of education; the existing assessment of the quality of education is currently reduced to its monitoring and does not allow making managerial decisions; the low level of use of information technology in processing the results of studies of various indicators of the quality of education, which negatively affects the labor costs of employees of this organization; information inaccessibility of an assessment for interested persons.

3. A model of an intra-school system for assessing the quality of education is proposed taking into account the recommendations of the current legislation, indicators for assessing the quality of education of an educational organization are developed, the need for the introduction of modern information and communication technologies to support and implement procedures for assessing the quality of education is justified.

\section{REFERENCES}

[1] Arkhipova, T.V., Sagdiyeva, M.S. i dr. (2017), 'Razrabotka i osobennosti funktsionirovaniya vnutrishkol'noy sistemy otsenki kachestva s prioritetnym vnedreniyem kriterial'nogo podkhoda', Upravleniye kachestvom obrazovaniya: teoriya i praktika effektivnogo administrirovaniya, 7, 39-52.

[2] Bolotov V.A. (2018), 'Proshloye, nastoyashcheye i vozmozhnoye budushcheye rossiyskoy sistemy otsenki kachestva obrazovaniya', Voprosy obrazovaniya, 3, 287 297.

[3] Zagvyazinskiy, V. I. (2010), 'Aktual'nyye problemy i perspektivy razvitiya obrazovatel'noy sistemy Rossii', Munitsipal'noye obrazovaniye: innovatsii i eksperiment, 5, 3-6.

[4] Metodicheskiye rekomendatsii po formirovaniyu modeli vnutrenney sistemy otsenki kachestva obrazovaniya V obshcheobrazovatel'nykh organizatsiyakh Vologodskoy oblasti // URL: http://viro.edu.ru/attachments/article/4652/metodmater. pdf

[5] Panasyuk, V.P. (2000) Sistemnoye upravleniye kachestvom obrazovaniya v shkole : monografiya / V.P. Panasyuk. - $\quad$ Sankt-Peterburg: Rossiyskiy gosudarstvennyy pedagogicheskiy universitet im. A.I. Gertsena, 239.

[6] Strategiya razvitiya informatsionnogo obshchestva $v$ Rossiyskoy Federatsii na 2017-2030 gody // URL: http://pravo.gov.ru/proxy/ips/?docbody $=\& n d=1024316$ $\underline{87}$

[7] Suvorova, A.P., Sudakova, N.YU. (2019) 'Diagnostika gotovnosti ekonomiki RF k tsifrovoy transformatsii', Problemy ustoychivogo razvitiya: otraslevoy i regional'nyy aspekt: materialy mezhdunarodnoy nauchno-prakticheskoy konferentsii, tom 1, 249-254.

[8] Federal'nyy zakon "ob obrazovanii v rossiyskoy federatsii" ot 29.12.2012 n 273-fz (poslednyaya redaktsiya) // url: http://www.consultant.ru/document/cons_doc_law_140 174/

[9] Gordon, G. (1998), 'Approaches to effective internal processes to quality management: an initial analysis', Tertiary Education and Management, Vol. 4, №4, 295 301. 
[10] Indicateurs de l'yducation au Canada: une perspective internationale - 2014 // URL: http:// www.statcan.gc.ca/pub/81-604-x/81-604x2014001-fra.pdf

[11] Ovodenko, A., Bezzateev, S., Mukhina, O., Andreeva, E., Ivanova, A., Vlasova, O., Goncova, A. (2013), 'Methodology of using distributed systems in advanced-level language learning', Proceedings of the 2013 International Conference on Advanced ICT and Education.

[12] Parasuraman, A., Berry, L., Zeithaml, V. (1988), 'SERVQUAL: A multiple- item scale for measuring customer perceptions of service quality', Journal of Retailing, 69 (Spring), 12-40.

[13] Sovetova, N., Kulachinskaya, A. (2019), 'Theoretical and practical aspects of transparency of local governments of rural settlements', International Scientific-Practical Conference "Business Cooperation as a Resource of Sustainable Economic Development and Investment Attraction", 52-56.

[14] Tereshchenko, E. (2015), 'The historical review of the legal reforms of the russian and south ossetian systems of education', Life Science Journal. T.12, № 1S, 65-69. 